\title{
The widening health gap: what are the solutions?
}

\author{
GEORGE DAVEY SMITH, DANNY DORLING, \\ DAVID GORDON \& MARY SHAW \\ Department of Social Medicine, University of Bristol, UK
}

\section{Introduction}

Throughout the long 18 years of Conservative government the Labour party referred to the issue of increasing social inequalities in health as an area of particular concern. Before the May 1997 election Labour announced that it would launch an Independent Inquiry into inequalities in health. The Inquiry was launched in July 1997, and at the launch Tessa Jowell, the Minister for Public Health, criticized the health strategy of the previous administration for "its excessive emphasis on lifestyle issues" which "cast the responsibility back on to the individual". Tessa Jowell gave a commitment regarding the Independent Inquiry's findings that these "conclusions, based on evidence, will contribute to the development of a new strategy for health". ${ }^{1}$

The Independent Inquiry report has now appeared. ${ }^{2}$ It presents a wealth of evidence on the extent and trends of inequalities in health. Together with a large body of other evidence the new report demonstrates clearly that the last two decades have seen large and growing inequalities in income in Britain, and that these have been accompanied by equally stark increasing inequalities in health and in life chances more generally.

The main task of the Independent Inquiry was to produce recommendations for policies that could alleviate inequalities in health. In fact 39 recommendations, many with sets of sub-recommendations, are given. While these contain some focused policies, the overall force of the recommendations is considerably weakened by a lack of prioritization; by being inadequately concrete; and by being uncosted. ${ }^{3}$

\section{No prioritization}

The recommendations are not presented in any hierarchy and the essential fact that inequalities in health follow closely on inequalities in wealth is underemphasized. The one (of 39) sets of recommendations on the necessity to reduce poverty and income inequalities thus appears to have the same status as 
those regarding reducing traffic speed, or offering concessionary fares to pensioners. The fundamental role of inequalities in material circumstances in producing the inequalities in other exposures is therefore missed and it is possible that many of the recommendations could be adopted-at least nominally-without addressing the underlying determinants of health inequalities.

\section{Inadequately concrete}

Many of the sets of recommendations are too vague to be useful. Recommending "measures to prevent suicide among young people, especially among young men and seriously mentally ill people" or "the development of policies to reduce the fear of crime and violence, and to create a safe environment for people to live in" would receive universal support, but they are of little use if it is not specified how these things are to be brought about. For example, the report advocates the development of a high-quality public transport system which is affordable to the user and specifically refers to the large relative increases in rail fares compared with motoring costs, but fails to make the obvious link with the privatization of the railways.

\section{No costings}

As the recommendations are not costed it is impossible to evaluate the relative costs of their implementation, the predicted social benefits which would follow and the opportunity costs of not investing in other areas. This lack of costing will allow the recommendations to be side-stepped by declaring that they are unrealistic and cannot be implemented in the current economic climate.

The last major report on inequalities in health was that of the committee chaired by Sir Douglas Black (which produced the Black Report ${ }^{4}$ ), commissioned by the last Labour government in 1977 and reporting to the then new Conservative administration in 1980. The Black Report discussed the inequalities in health and in income that existed at the time and made a series of policy recommendations. These were rejected by Patrick Jenkin (then the Secretary of State for Social Services) as being unrealistic and the report was deliberately released before a national holiday, with no official press release or press conference and with only 260 copies produced.

For 17 of the 18 years of Conservative government the Labour Party made political capital out of the non-implementation of the recommendations of the Black Report. Indeed the enthusiasm for addressing inequalities in health was one element that survived the transformation from old to new Labour. A few weeks before the May 1997 Labour election victory Baroness Jay-now Leader of the House of Lords and Minister for Women - stated that the Black Report "provided the essential base and policy guide to any responsible government wanting to take action" on inequalities in health. She committed the incoming Labour government to a health strategy in which the distribution of economic 
resources would be a key element. ${ }^{5}$ In the same debate another Labour peer stated that the "failure since 1980 to implement any of the Black Report recommendations has caused disappointment to many and must have caused a great deal of needless suffering on the part of many of the poorest families".

In the light of Labour's long-term declared policy on inequalities in health it is very disappointing that a major limitation on the Independent Inquiry was its brief from the government, which stated that it had to be carried out "within the broad framework of the Government's overall financial strategy". This constrained the Inquiry from proposing markedly redistributive fiscal policies, given some of the commitments on taxation made by Labour before the last election.

In this paper we consider the current evidence on increasing socioeconomic inequalities in health, in many cases using data which are more recent than those available to the Independent Inquiry. Our focus is on socioeconomic differentials, not on the important differences in health status and health service access which are seen between ethnic groups or according to gender or sexuality. When reading the information contained in our report it is worth remembering that the Black Report was commissioned in 1977, when inequalities in income were at a historic low point. In $1977,7 \%$ of the population were on incomes below half of the average after housing costs; in 1995-96 this had more than trebled to $24 \% .^{6}$ The increasing inequalities in income, which have resulted in the UK leading the developed world in income inequality and child poverty, ${ }^{7}$ started under the last Labour government, in 1977. Tony Blair has declared that "I believe in greater equality. If the Labour government has not raised the living standards of the poorest by the end of its time in office it will have failed". 8 To ensure it does not fail, the Government should take the Independent Inquiry's evidence seriously and reconsider its stance of distancing itself yet further from redistributive social policies.

\section{Inequalities in health in Britain}

\section{Mortality rates in different communities}

The widening health gap in Britain can be seen when considering the difference in mortality rates between communities living in different parts of Britain. Table 1 lists the 20 areas (County Boroughs and urban and rural remainders of counties) which were reported as having the highest Standardised Mortality Ratios $\left(\mathrm{SMR}^{\mathrm{a}}\right)$ in 1990-92. In nearly all of these 20 areas the SMRs increased between the early 1990s (1990-92) and the mid-1990s (1993-95).

In the period 1993-95 the same areas that had high SMRs in 1990-92 have even higher SMRs a few years later. This demonstrates the importance of structural factors in determining life chances. A person's likelihood of dying young is not a matter of chance, since their social position and their life trajectory are conditioned by the social circumstances of the community in which they live. 
TABLE 1. Ranked SMRs under 65 for the 20 areas with the highest mortality in 1990-92, with SMRs for 1993-95.

\begin{tabular}{lcc}
\hline $\begin{array}{l}\text { Rank Area } \\
\text { 93-95 }\end{array}$ & $\begin{array}{c}\text { SMR }<65 \\
1990-92\end{array}$ & $\begin{array}{c}\text { SMR }<65 \\
1993-95\end{array}$ \\
\hline 1. Glasgow County of City & 179 & 196 \\
2. Shoreditch & 169 & 166 \\
3. Greenock Burgh & 168 & 189 \\
4. Salford & 166 & 163 \\
5. Port-Glasgow Burgh & 166 & 180 \\
6. Clydebank Burgh & 163 & 154 \\
7. Oldham & 157 & 149 \\
8. Southwark & 155 & 151 \\
9. Middlesbrough & 154 & 145 \\
10. Coatbridge Burgh & 153 & 161 \\
11. Dumbarton Burgh & 148 & 152 \\
12. Manchester & 147 & 158 \\
13. Lambeth & 147 & 149 \\
14. Hammersmith & 147 & 154 \\
15. Preston & 146 & 149 \\
16. Bermondsey & 144 & 169 \\
17. Hamilton Burgh & 143 & 154 \\
18. Rutherglen Burgh & 141 & 158 \\
19. Poplar & 141 & 146 \\
20. Warrington & 141 & 146 \\
Overall in these areas & 158 & 167 \\
England and Wales & 100 & 100 \\
\hline
\end{tabular}

If we consider the SMRs for all 292 of these areas in Britain, grouped according to deciles ('tenths') of the population (Table 2), then we can see that the gap in deaths between the best tenth and worst tenth of the British population had grown wider by the mid-1990s (1993-95) than at any time since the 1950s. The SMR of the decile with the highest mortality in 1990-92 $(\mathrm{SMR}=142)$ is even higher in 1993-95 $(\mathrm{SMR}=147)$. In terms of absolute numbers of deaths, 45,095 people died in the $10 \%$ of areas with the highest mortality in 1993-95 compared with 27,738 in the $10 \%$ of areas with the lowest mortality. The ratio of the death rates in the worst and best $10 \%$ areas has been increasing since the late 1960s/early 1970 s, but increased most rapidly during the 1980 s.

It could be argued that the polarization of mortality ratios shown in Table 2 is an artefact of the method used to rank areas by mortality ratios and is not indicative of a polarization of health inequalities by poverty, income and wealth. To counter this possibility we have recalculated the SMRs for people in Britain according to the average incomes of people in the workforce in the areas in which they live, estimated from 1991 census data by parliamentary constituency. From Table 3 it can be seen that the poorest $10 \%$ of the population, living 
TABLE 2. Age-sex Standardised Mortality Ratio for deaths under 65 in Britain by deciles of population.

\begin{tabular}{lccccccc}
\hline Decile & $1950-53$ & $1959-63$ & $1969-73$ & $1981-85$ & $1986-89$ & $1990-92$ & $1993-95$ \\
\hline 1. & 131.0 & 135.5 & 131.2 & 135.0 & 139.2 & 142.3 & 147.4 \\
2. & 118.1 & 123.0 & 115.6 & 118.6 & 120.9 & 121.4 & 120.9 \\
3. & 112.1 & 116.5 & 112.0 & 114.2 & 113.9 & 111.3 & 112.7 \\
4. & 107.0 & 110.7 & 108.1 & 109.8 & 106.9 & 104.9 & 106.7 \\
5. & 102.5 & 104.5 & 103.0 & 102.1 & 102.2 & 99.0 & 98.5 \\
6. & 98.6 & 97.4 & 96.9 & 95.7 & 95.6 & 93.5 & 94.6 \\
7. & 93.1 & 90.9 & 91.8 & 91.6 & 91.9 & 90.9 & 91.7 \\
8. & 88.7 & 87.6 & 88.9 & 89.3 & 89.1 & 86.5 & 86.6 \\
9. & 85.7 & 83.1 & 87.0 & 84.3 & 83.0 & 80.4 & 80.2 \\
10. & 81.8 & 77.1 & 83.0 & 79.2 & 78.1 & 76.2 & 74.5 \\
Ratio of worst tenth: best tenth & 1.6 & 1.8 & 1.6 & 1.7 & 1.8 & 1.9 & 2.0 \\
\hline \multicolumn{7}{r}{} \\
\hline
\end{tabular}

TABLE 3. Mortality ratios (under 65) by area by average income 1981-95.

\begin{tabular}{lrcrrr}
\hline SMR $<65$ all & $\begin{array}{c}\text { Average } \\
\text { income }\end{array}$ & $\begin{array}{c}\text { SMR } \\
1981-85\end{array}$ & $\begin{array}{c}\text { SMR } \\
1986-90\end{array}$ & $\begin{array}{c}\text { SMR } \\
1991-95\end{array}$ & $\%$ Change \\
\hline 1. & 9,785 & 127 & 131 & 134 & 8 \\
2. & 10,508 & 118 & 119 & 120 & 2 \\
3. & 10,904 & 110 & 110 & 108 & -2 \\
4. & 11,200 & 103 & 104 & 101 & -2 \\
5. & 11,446 & 101 & 100 & 100 & -1 \\
6. & 11,728 & 99 & 99 & 97 & -2 \\
7. & 12,039 & 94 & 93 & 90 & -4 \\
8. & 12,330 & 89 & 87 & 84 & -4 \\
9. & 12,744 & 87 & 86 & 83 & -4 \\
10. & 13,485 & 84 & 81 & 80 & -4 \\
\hline
\end{tabular}

in areas with average incomes for those in the workforce of $£ 9785$, saw mortality ratios rise from 127 to 134 over the last 10 years, whereas the richest $10 \%$ saw mortality ratios fall over this period. We can only calculate these ratios by income for the 1980 s and 1990s but it is apparent that the polarization in mortality has followed the polarization of incomes geographically.

\section{Infant mortality}

The widening gap in health by social class can be seen not only in the mortality rates of adults. In his last report as Chief Medical Officer ${ }^{10}$ Sir Kenneth Calman highlights in his introduction a number of overall improvements in health, including the fact that infant mortality has reached its lowest recorded rate, of 5.9 deaths per 1000 live births. However, a closer inspection of these rates 


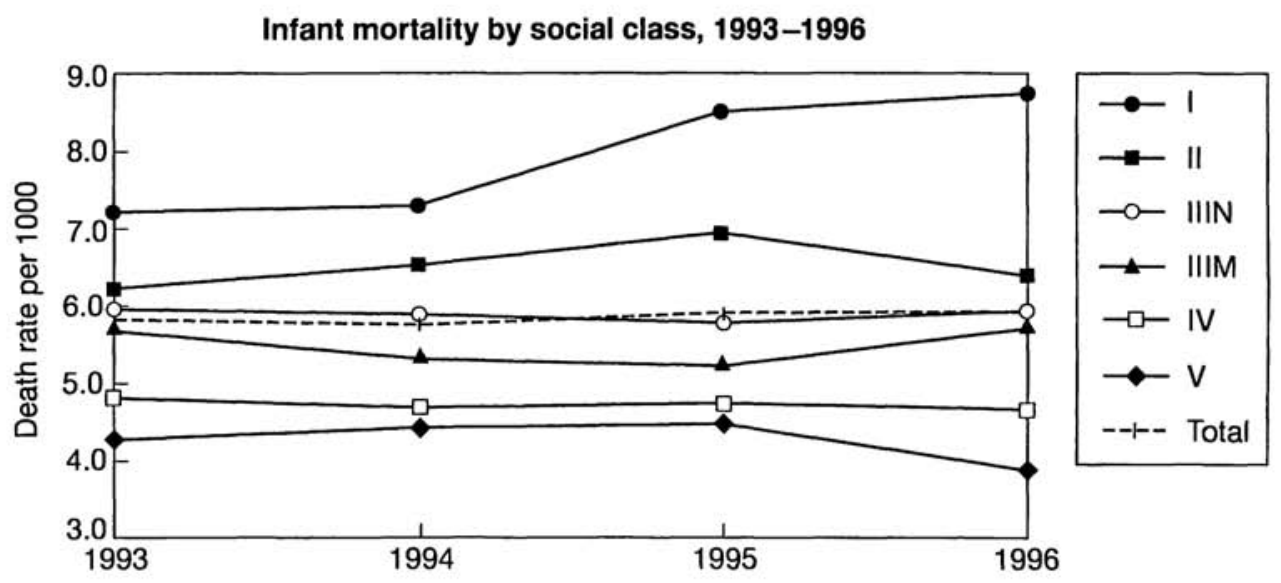

FIGURE 1. Infant mortality by social class, 1993-96.

reveals that overall infant mortality rates have levelled off in the past 4 years, but when these rates are considered by social class (of father) a different picture emerges. As Figure 1 shows, there are growing differences between the death rates of babies with social class I fathers (professional occupations) and babies with social class $\mathrm{V}$ fathers (unskilled manual workers)-babies of unskilled manual workers are 2.2 times more likely to die than babies with fathers in professional occupations. For every 1000 babies born whose father is social class $\mathrm{V}$, eight babies have died within their first year.

These trends are based on only a few years - because of changes in how data are reported-and a relatively small number of deaths. Therefore, it is important to monitor the infant mortality rate by social class over the coming years to see if this worrying trend continues.

\section{Mortality and social class}

While life expectancy has been rising for both men and women throughout the century not all social groups have enjoyed the same improvements. The difference in life expectancy between social classes has widened such that on average a man from a professional or managerial occupation (classes I and II, such as a doctor or lawyer), can expect to live 5.2 years longer than a man who works in a semi- or unskilled manual job (classes IV and V). ${ }^{11}$ For women, the difference is 3.4 years. This difference means that a male labourer was 2.9 times more likely to die at any time before retirement than a doctor or a lawyer. This is the widest gap reported since 1921, when the government first reported figures in this way, and it continues to grow.

Table 4 shows standardized mortality ratios for men of working age by social class from 1921 to 1993 . From this it can be seen that the mortality gap between classes V (unskilled manual jobs) and I (professional occupations) has been growing since the 1930 s. 
TABLE 4. SMRs for men under 65 by social class, 1921-93.*

\begin{tabular}{lccccc}
\hline & I & II & IV & V & Ratio class V:I \\
\hline $1921-23$ & 82 & 94 & 101 & 125 & 1.5 \\
$1930-32$ & 90 & 94 & 102 & 111 & 1.2 \\
$1949-1953$ & 86 & 92 & 104 & 118 & 1.4 \\
$1959-1963$ & 76 & 81 & 103 & 143 & 1.9 \\
$1970-1972$ & 77 & 81 & 114 & 137 & 1.8 \\
$1979-1983$ & 66 & 76 & 116 & 165 & 2.5 \\
$1991-1993$ & 66 & 72 & 116 & 189 & 2.9 \\
\hline
\end{tabular}

*Social class III was divided into two groups - III non-manual and III manual from 1970 onwards and so has been omitted from the table.

TABLE 5. Annual age adjusted rate of years of potential life lost per 1000 of the population (data refer to males aged 20-64, all causes of death, England and Wales). ${ }^{13}$

\begin{tabular}{lccc}
\hline Social class & $1970-72$ & $1979-80,1982-83$ & $1991-93$ \\
\hline I & 49 & 37 & 28 \\
II & 52 & 42 & 32 \\
III non-manual & 65 & 54 & 46 \\
III manual & 66 & 58 & 51 \\
IV & 76 & 68 & 53 \\
V & 103 & 106 & 93 \\
Ratio V:I & 2.1 & 2.9 & 3.3 \\
\hline
\end{tabular}

We can also see the widening gap in health by social class in terms of 'Years of Potential Life Lost'. While standardized mortality ratios have the advantage of taking into account the different age structures of the social class groups, they are heavily influenced by the number of deaths occurring in the oldest age category. However, the largest relative class differences in absolute mortality are at younger ages, and so it is also worth considering the relative number of years of productive life that are lost through premature mortality. As Table 5 shows, the ratio of years of life lost for social class V as compared with social class I between the early $1970 \mathrm{~s}$ and early $1990 \mathrm{~s}$ rose from 2.1 to $3.3 .{ }^{13}$

\section{Increases in poverty and inequality}

Poverty and income inequality in Britain are now greater than at any time since the 1930s. Poverty and inequality have increased particularly rapidly since 1979 . This alarming increase was a direct result of successive Conservative government economic and social policies that were designed to promote efficiency and reduce inflation. These had the effect of increasing unemployment, increasing 
indirect taxes that affect the poorest most and reducing the adequacy of welfare benefits.

Inequality and poverty have increased much faster in Britain over the past 20 years than in almost any other country. For example, Bradshaw \& Chen (1997) looked at levels of poverty in Australia, Canada, Germany, Israel, The Netherlands, Norway, Sweden, Taiwan, UK, and USA in circa 1979, 1985 and 1990. Poverty was defined as households below half $(50 \%)$ average income after social security benefits and direct taxes ${ }^{14}$. They conclude:

There has been an increase in poverty in all countries except Israel and Canada over this period between 1979 and 1990 but by far the sharpest increase in poverty has occurred in the UK where between 1979 and 1990 the poverty rate more than doubled. (1997, p. 17)

Other evidence suggests that income in equality - the inequitable distribution of income in the population-increased faster in Britain over the period 1967-92 than in comparable countries (Table 6).

As shown in Table 7, over the same period the child poverty rate has also increased at a faster rate in Britain than in other comparable countries (many of which saw a reduction in the rate).

The rapid growth of inequality and poverty in Britain can be seen clearly from official statistics on the percentage of the population living in households with incomes of less than half the average after allowing for differences in housing costs. This is the poverty/income inequality measure that is currently favoured by both the British government and the European Statistical Office (Eurostat).

TABLE 6. Increases in income inequality, 1967-92.

\begin{tabular}{ll}
\hline Increase (\%) & Country \\
\hline More than 30 & UK \\
$16-29$ & USA, Sweden \\
$10-15$ & Australia, Denmark \\
$5-10$ & Norway, Netherlands, Belgium \\
around 0 & Spain, France, Finland, Canada, Germany \\
Decreases & Italy \\
\hline
\end{tabular}

TABLE 7. Increases in child poverty, 1967-92. ${ }^{7}$

\begin{tabular}{ll}
\hline Increase (\%) & Country \\
\hline More than 30 & UK, USA \\
$10-15$ & Norway \\
$5-10$ & Netherlands, Belgium, Germany \\
around 0 & Australia, Spain, France \\
Decreases & Sweden, Denmark, Finland, Canada, Italy \\
\hline
\end{tabular}




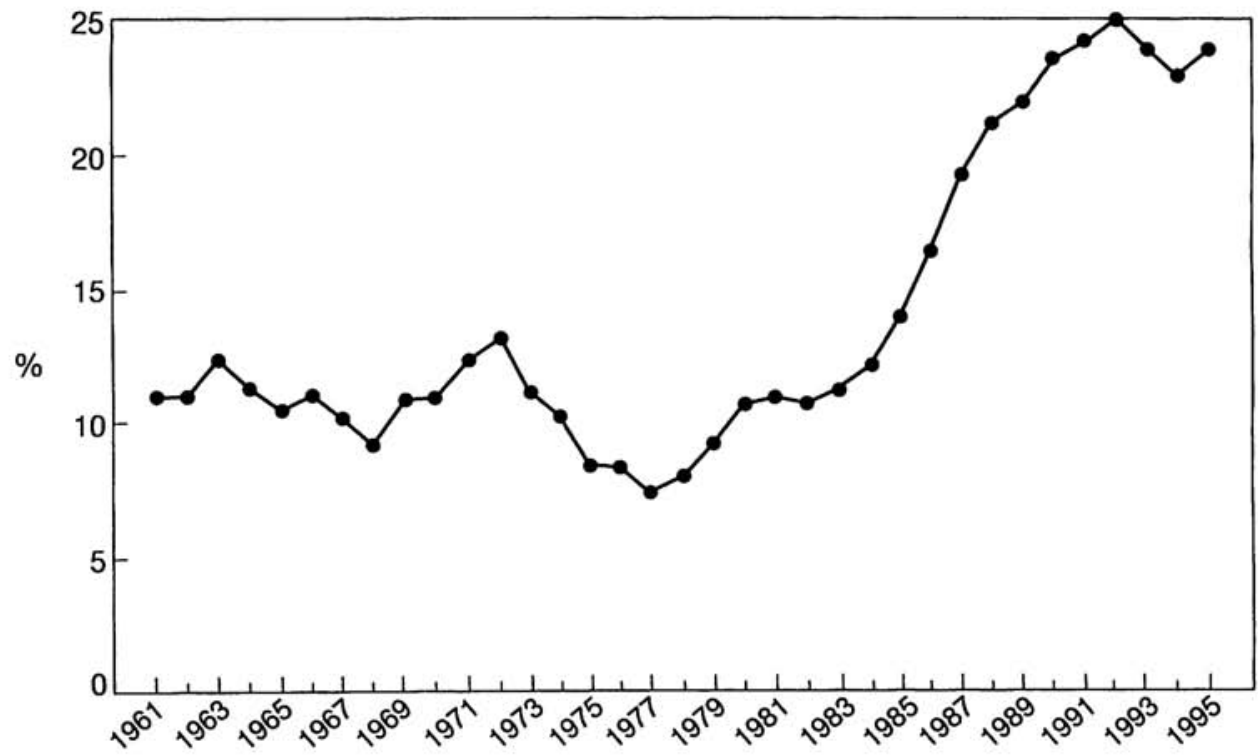

FIGURE 2. Percentage of the population with below half average incomes after housing costs Source: ${ }^{15-17}$ (1961-95).

Figure 2 shows that during the 1960s the amount of income inequality in Britain remained fairly constant with around $11 \%$ of the population living on incomes below half of the average. The recession and stagflation of the early 1970s caused by the OPEC oil price increases lead to the numbers living on less than half average incomes to rise to a peak of just over $13 \%$. The relatively progressive government social and economic policies until the mid-1970s resulted in poverty and inequality falling rapidly to a low of under $8 \%$ of the population in $1977-78 .{ }^{15}$ From this point a rise in income inequality occurred. The 1979 election victory of the Conservative party under Margaret Thatcher's leadership caused a rapid growth in poverty and inequality which increased throughout the 1980s and early 1990s. By 1995-96 almost a quarter (24\%) of the British population were living on incomes that were so low that they were below half the average income.

Similarly, studies that examine poverty in terms of both low income and low standard of living (high deprivation) have shown that poverty increased by almost $50 \%$ between 1983 and $1990^{18}$. In 1983, 14\% of households (approximately 7.5 million people) were living in poverty and, by $1990,20 \%$ of households (approximately 11 million people) were living in poverty.

Table 8 shows that, after housing costs, the richest $10 \%$ of the population have $27 \%$ of total income, whereas the poorest $10 \%$ have only $2.2 \%$ of total income. This compares with $21 \%$ and $4 \%$, respectively, in 1979 .

Britain is now a country where the richest 50 people in 1996 had income and wealth of over $£ 34$ billion, ${ }^{19}$ which is far in excess of the wealth and incomes of 
TABLE 8. Distribution of income: households below average income series, 1979 to $1994-95 .{ }^{\star}$

\begin{tabular}{|c|c|c|c|c|c|c|c|c|c|c|}
\hline & \multicolumn{2}{|c|}{ Poorest 2} & 3 & 4 & 5 & 6 & 7 & 8 & 9 & Richest \\
\hline \multicolumn{11}{|c|}{ (a) before housing costs } \\
\hline 1979 & 4.3 & 5.7 & 6.6 & 7.6 & 8.5 & 9.5 & 10.7 & 12.2 & 14.2 & 20.6 \\
\hline 1981 & 4.0 & 5.6 & 6.5 & 7.4 & 8.4 & 9.5 & 10.7 & 12.2 & 14.5 & 21.1 \\
\hline 1987 & 3.6 & 5.0 & 5.9 & 6.9 & 8.0 & 9.1 & 10.4 & 12.2 & 14.9 & 24.2 \\
\hline $1990 / 91$ & 2.9 & 4.5 & 6.0 & 6.0 & 8.0 & 9.0 & 11.0 & 12.0 & 15.0 & 26.0 \\
\hline $1992 / 93$ & 2.9 & 4.6 & 6.0 & 6.0 & 8.0 & 9.0 & 10.0 & 13.0 & 15.0 & 26.0 \\
\hline $1994 / 95$ & 3.2 & 4.7 & 6.0 & 6.0 & 8.0 & 9.0 & 10.0 & 12.0 & 15.0 & 26.0 \\
\hline \multicolumn{11}{|c|}{ (b) after housing costs } \\
\hline 1979 & 4.0 & 5.6 & 6.6 & 7.5 & 8.5 & 9.5 & 10.8 & 12.3 & 14.3 & 20.9 \\
\hline 1981 & 3.7 & 5.4 & 6.3 & 7.3 & 8.3 & 9.5 & 10.7 & 12.3 & 14.7 & 21.8 \\
\hline 1987 & 2.9 & 4.6 & 5.6 & 6.7 & 7.6 & 9.1 & 10.6 & 12.3 & 15.1 & 25.0 \\
\hline $1990 / 91$ & 2.1 & 4.1 & 5.0 & 7.0 & 7.0 & 10.0 & 10.0 & 12.0 & 16.0 & 27.0 \\
\hline $1992 / 93$ & 1.9 & 4.1 & 5.0 & 6.0 & 8.0 & 9.0 & 10.0 & 13.0 & 15.0 & 28.0 \\
\hline $1994 / 95$ & 2.2 & 4.1 & 6.0 & 6.0 & 8.0 & 9.0 & 10.0 & 12.0 & 16.0 & 27.0 \\
\hline $1995 / 96$ & 2.2 & 4.1 & 5.0 & 7.0 & 7.0 & 9.0 & 11.0 & 12.0 & 16.0 & 27.0 \\
\hline
\end{tabular}

Note: ${ }^{\star}$ Share of total income received by individuals below various percentiles of the income distribution including self-employed (income after housing costs)

Source: DSS. ${ }^{17}$

TABLE 9. Change in incomes (after housing costs) of the richest and poorest $10 \%$ of different types of families betwcen 1979 and 1995-96 (in April 1998 prices).

\begin{tabular}{lcc}
\hline Family type & Poorest 10\% & Richest 10\% \\
\hline Single adult & $-£ 208$ & $+£ 6968$ \\
Couple with no children & $-£ 364$ & $+£ 12688$ \\
Couple with 3 children aged 3,8 \& 11 & $-£ 624$ & $+£ 21164$ \\
\hline
\end{tabular}

Source: DSS. ${ }^{19}$

the 'poorest' 5.5 million Britons (5.5 million people is approximately the population of a city the size of Greater London).

Table 9 shows the changes in incomes of the poorest and richest $10 \%$ of families between 1979 and $1995-96$. The poorest $10 \%$ of single adult households received, on average, $£ 208$ less in $1995-96$ than in 1979. By comparison the richest $10 \%$ of single adult households were $£ 6968$ richer in 1995-96 than in 1979. The situation was even worse for large families with three children where the poorest $10 \%$ were on average $£ 625$ poorer in 1995-96 compared with 1979 and the richest $10 \%$ were over $£ 21000$ richer.

Hills $^{15}$ points to various factors driving the growth in inequality during the 1980s and 1990s:

- The gap between low and high pay grew, linked to declining importance of unions and of minimum wage protection. 
TABLE 10. Number and percentage of the population living on incomes below half of the average in 1994 in 14 European countries. ${ }^{20}$

\begin{tabular}{lrr}
\hline Country & $\begin{array}{c}\text { Number of people } \\
\text { below } 50 \% \text { of average income }\end{array}$ & $\begin{array}{c}\text { Percentage of the population } \\
\text { below 50\% of average income }\end{array}$ \\
\hline United Kingdom & $11,426,766$ & 20 \\
Germany & $11,327,673$ & 14 \\
Italy & $9,321,853$ & 17 \\
France & $7,949,907$ & 14 \\
Spain & $7,196,406$ & 19 \\
Portugal & $2,424,533$ & 25 \\
Greece & $2,041,923$ & 20 \\
Belgium & $1,474,158$ & 15 \\
Netherlands & $1,275,048$ & 8 \\
Austria & $1,108,082$ & 14 \\
Ireland & 837,490 & 23 \\
Denmark & 386,015 & 7 \\
Finland & 192,153 & 4 \\
Luxembourg & 56,734 & 14 \\
\hline
\end{tabular}

- The number of workless households rose faster than overall official unemployment, with more 'no-earner' and 'two-earner' households.

- Price-linking of benefits meant that benefit levels fell further behind the rest of the population when overall incomes rose.

\section{The European context}

Table 10 shows the numbers and proportions of the populations of 14 European countries living on incomes below half of the average in their countries after allowing for differences in the purchasing power of the different currencies. In absolute terms, Britain now has more people living on incomes below half the average than any other country in Europe (11.5 million people) and the third highest percentage of population living on below average incomes $(20 \%$ of the population ${ }^{20}$ ) after Ireland and Portugal.

\section{The impact of growing inequalities on health}

\section{Inequalities between communities}

It is not surprising that the health gap between different communities grew during the 1980s and continues to grow in the 1990s. Inequalities in many other areas of life grew first and these are reflected by the growing inequalities in health. For instance, unemployment rose at different rates in different places in Britain at the start of the 1980 s and many areas continue to be blighted by very high unemployment rates. The government has, so far, introduced no effective new policies designed to narrow the gap in unemployment rates between local 
areas. Many new jobs that are created in inner cities go to people who commute into these areas. A more focused set of policies is needed which do not simply concentrate on 'problem estates' but which look at the wider range of differences in opportunities found between areas. The children living in the richest quarter of areas in Britain have a $50 \%$ chance of going to university. Those in the poorest quarter have a $10 \%$ chance. Ways of narrowing community inequalities such as these are available to the government.

\section{Inequalities between regions}

For similar reasons it is not surprising that regional inequalities in health in Britain are amongst the widest in Europe. The recent rise in branch plant closures in peripheral regions suggests that the current and limited policies of what used to be called regional assistance are not working. New industries are unlikely to emerge in poorer areas without greater government assistance, whereas the Home Counties of England benefit from the indirect advantages of being near the seat of government. Greater regional autonomy should reduce this inequality, but so far this has only been suggested for London within England. The North of England, Wales, the far South West and much of Scotland suffer from their remoteness from power in the capital. It remains to be seen how much devolution will change this picture.

\section{Inequalities between children}

Similarly it would not be surprising to find that the mortality rates of children born to the poorest families in Britain continue to rise when the government has implemented policies such as reducing the single-parent premium, which will have had the greatest damaging effect on the poorest of children. Encouraging mothers to work will not reverse the rise in inequalities in mortality for children aged under one, most of whose mothers do not and cannot work. Improving the material living standards of their families would have a direct effect on the health of these children.

\section{Inequalities between families}

It is not surprising that inequalities in the health of adults in different social groups continue to grow when we know that the inequality in the incomes of their families has risen over this period and remains at very high levels. Most importantly, inequalities in wealth are higher than those of income. If these inequalities are not reduced then we should not expect to see reductions in the health inequalities between families in different social locations. The government's unwillingness to reverse the regressive taxation changes of the $1980 \mathrm{~s}$ and its reluctance to increase inheritance tax will help to maintain these inequalities and to ensure that the gap between the health of different families in Britain continues to grow. 


\section{Reducing inequalities in health}

The Independent Inquiry into Inequalities in Health reviewed the evidence on inequalities in health and presented a number of policy recommendations. However, the 39 sets of recommendations are not adequately prioritized. We consider that in order to reduce health inequalities, as the government has pledged in the recent Green Paper, ${ }^{21}$ policies must be aimed at their underlying cause. There is one central and fundamental policy that should be pursued: the reduction of income inequality and consequently the elimination of poverty. Ending poverty is the key to ending inequalities in health.

From the evidence we have provided, it is clear that the most effective way of reducing health inequalities in Britain is to reduce income inequality and poverty. Any child can tell you how this can be achieved: the poor have too little money so the solution to ending their poverty is to give them more money. Poverty reduction really is something that can be achieved by 'throwing money at the problem'.

Social policy researchers and economists have proposed a range of affordable and cost effective anti-poverty policies. Policies aimed at increasing the standard of living and incomes of poor families with children, disabled people and the elderly will have the greatest impact on reducing inequalities in health. The quickest and most cost-effective method of alleviating poverty is to increase the value of welfare benefits (especially for families with children) and pensions and improve public services and social housing. A powerful case for introducing a number of specific policies, by building on existing schemes, will be discussed in the next section.

Economists have also designed and costed a number of 'affordable' basic income schemes that if properly implemented would effectively end poverty in Britain. ${ }^{22} \mathrm{~A}$ Basic Income is a payment received by every person or household, which provides a minimum income, and the amount is based on only age and family status, but is otherwise unconditional.

There are three main advantages claimed for basic income schemes: ${ }^{22}$

1. They should plug the gaps and loopholes in social security and reduce the number of people living in poverty.

2. They should remove unemployment and poverty traps that result from the high rates of benefit withdrawal when the unemployed obtain work, or people with low incomes move up the earnings ladder.

3. They are desirable because people should have a means of subsistence which is independent of needs and not dependent on complicated contribution records or intrusive scrutiny of personal means.

Most existing social security benefits in industrialized countries are contingent. That means that they are related to misfortune or conditions such as age, sickness or unemployment. By contrast, a basic income depends only on very general characteristics such as number of dependants. There are no questions or conditions relating to effort to find work, state of health, contribution records 
or capital holdings. Basic Incomes could replace many existing specific social security benefits. There would always be people with special needs requiring extra sums on a conditional or discretionary basis but fewer cases than at present. Some advocates believe that basic income payments should take the form of a tax credit to be set off against tax but received as a positive payment from the state by those with insufficient tax liabilities.

The government has recently proposed implementing legislation to provide a guaranteed minimum income for working families with children of $£ 180$ per week from April 1999, increasing to $£ 190$ per week in October 1999. Pensioners will also have a guaranteed minimum income of $£ 75$ for single people and $£ 117$ for couples from April 1999. Similarly, severely disabled people who are unable to work will be guaranteed a minimum income of $£ 128$ per week. However, these proposals do not go much beyond existing levels of income support and family credit and, like all existing means tested benefits, will fail to reach large numbers of those legally entitled to those benefits. In practice, the proposals will make little difference to existing living standards especially when, as in the case of Incapacity Benefit, the government is proposing to save more money in cuts than it is prepared to spend on additions to selected means-tested benefits for severely disabled adults and young children.

The political will does not presently exist to implement a broad-based minimum income guarantee for the whole population at a sufficient level to end poverty. In the absence of this, a number of specific targeted policies could be implemented that would reduce poverty amongst the elderly, the sick and disabled and families with children. These would have the effect of also reducing inequalities in health.

\section{Child poverty and health}

The experience of poverty and deprivation during childhood can have lifelong consequences on health. One of the most worrying aspects of the growth in poverty and inequality over the past 20 years has been the very high rates of poverty experienced by lone-parent families, families with young children and large families. ${ }^{23}$

The government's proposed increase in Child Benefit is welcome but does not cover all children, and is in large measure a catching-up exercise because of the fall in the real value of this benefit in recent years. Child Benefit is the key factor in any policy designed to raise family living standards. The Black Report recommended that Child Benefit should be fixed at $5.5 \%$ of average gross earning and this policy should be implemented.

It is essential for reducing inequalities in child health that all pregnant women are able to afford an adequate diet. Budget Standards research at the University of York and Loughborough indicates that the current maternity allowance is insufficient to achieve this aim. The abolition of the universal maternity allowance was a retrograde step. Maternity entitlements need to be increased, particularly for women dependent on income support and/or in low-paid jobs. 
A third of all children live in families dependent on Income Support and a third of all children are born into families that are dependent on income support. The scale rates are therefore one of the most crucial factors that determine the amount of child poverty in Britain. These are currently so low that families with children will eventually sink into poverty if they become dependent on Income Support for any length of time. Additional benefits are required to support families with children.

Approximately a quarter of all children are born to mothers under 25 years old. Therefore, the supposition that people aged less than 25 require less benefit than those over 25 needs to be re-examined urgently.

Adequate additional benefits are needed by lone parents following the abolition of the Lone Parent premium. Lone-parent families face additional financial and time costs compared with two-parent households and the level of benefits available to lone-parent families needs to reflect adequately these additional costs.

Means-tested benefits are a costly and inefficient method of alleviating poverty as they rarely can achieve better than $80 \%$ take-up rate. Universal child benefit rates should therefore be increased to $5.5 \%$ of average gross earnings.

Although increasing the value of benefits available to families with children is the most imporcant social policy for reducing poverty and inequalities in health, there are also a number of specific polices of secondary importance which will also help reduce child poverty and childhood deaths and illness.

The rent limit on housing benefit needs to be removed for families with children and increased building of social housing is required to end the need for bed-and-breakfast accommodation. Subsidies for Social Housing would also enable real rent levels to be reduced. The essential policy aim needs to be the reduction of child poverty, as indicated by our suggestions above. There are other policy recommendations which deserve consideration. We list some of these below:

- The mortality rate of pedestrians in road traffic accidents (RTAs) in Britain is one of the highest in the industrialized world. Pedestrian child deaths and injury due to RTAs have a steep poverty gradient. An immediate and rigid enforcement of the speed limits in residential areas would be the most rapid and inexpensive means of reducing inequalities in health. The law needs to be enforced and the technology to achieve this (traffic-calming measures, speed cameras, etc.) is both readily available and relatively cheap. Speed traps might well prove to be income generating.

- Nutritional standards for school meals have now been reintroduced but new technology (e.g. smart cards) needs to be employed to remove the stigma from free school meals. Free school meals entitlement should be extended to families receiving family credit and free school milk provision should be made mandatory. School breakfast schemes should be examined, and where successful be extended. 
- An effective educational campaign needs to be introduced to reduce teenage pregnancies.

The imprisonment and criminalization of parents for non-payment of debt (particularly TV licence offences) needs to be stopped.

- Subsidized childcare and after-school care places are needed to enable parents to take up paid work. Progress is currently being made in this area.

\section{Old age and ill health}

The elderly are more likely to die or be ill than any other group. Poverty in old age exacerbates this situation; poor pensioners are more likely to become sick or disabled than richer pensioners and if they become ill poor pensioners are more likely to die younger. ${ }^{24}$ The most effective way of alleviating poverty amongst the elderly is through pensions policy, and Barbara Castle and others ${ }^{25}$ have recently proposed that:

The government should fulfil its Manifesto commitment to make the basic state pension the foundation of its pensions policy by immediately restoring the earnings link.

The currently level of the state pension is too low and needs to be increased to an adequate level by a one-off topping-up exercise along the lines advocated by John Smith in 1992. The government should be aiming at reducing means testing, not extending it.

The government should ensure that everyone makes an adequate minimal provision for their retirement by compelling them to contribute to a second-tier pension sufficient to lift them out of dependency on means-tested benefits. The Conservative Governments of 1979 to 1997 slashed the State Earnings Related Pension Scheme (SERPs), which had been introduced with all-party support in the 1970s. A modernized version of SERPs would be comprehensive and meet the needs of people on low incomes, unlike the stakeholder pension alternative proposed by the government. A return to the 'twenty best years formula' when pensions reflect the peak earnings of people during their working lives is important for manual and part-time workers and women whose working lives are interrupted by family responsibilities.

Good quality occupational pensions need to be encouraged and tighter regulation of personal pensions is required to prevent mis-selling.

\section{Disability, long-term illness and poverty}

Poverty and lack of adequate income are amongst the main reasons why disabled people often become ill and why ill health can often persist. It is self-evident that inequalities in health can be reduced if the standard of living of long-term sick and disabled people can be improved. Yet welfare and benefits policy towards this group throughout much of the twentieth century can best be described as "irrational, inequitable and inadequate"; policy development was 
plagued by "Haphazard and piecemeal incrementalism ... when money was available or pressure strong, and ... grafted onto existing systems. Nothing has been jettisoned and nothing rethought from first principles". ${ }^{26}$ The 1980 s were described as "disastrous for disabled people, involving threats to opportunities, living standards, independence and choice". ${ }^{27}$

It is therefore unsurprising that analysis of government surveys has shown that $60 \%$ of disabled people have to claim safety net benefits and $47 \%$ of them did not have enough to meet their minimum costs. ${ }^{28}$ Independent surveys of families with disabled children have also shown that "For many, their greatest need was for more financial assistance.... Most parents felt higher weekly disability benefits would be the best way to provide further financial assistance". ${ }^{29}$ This is a clear message that requires specific policies.

The levels of disability benefits are too low to prevent poverty and they need to be increased, substantially in some cases to meet the additional costs of disability and ill health. This applies in particular to Disability Living Allowance and Incapacity Benefit. The rates of long-term disability benefits should be linked to earnings, not prices. There is a need for mental health component criteria to be introduced into the assessment for Disability Living Allowance.

A Disability Earnings Concession (DEC) should be introduced which allows people in receipt of disability benefits to work and earn as and when their health allows it, without any risk to benefit entitlement. Working thus has no effect on benefits. But a higher tax code for DEC earners will deduct the usual tax and National Insurance, plus a reasonable percentage towards DSS, council tax and housing benefits when that person does work (Disability Living Allowance would be excluded from this consideration). Elizabeth Bray has put forward detailed proposals.

The cuts in funding and eligibility criteria of the Access to Work Scheme need to be restored. Finally a fully inclusive educational system is needed that delivers the same standard of education to both disabled and non-disabled children alike.

However, the exclusion experienced by sick and disabled people will not end while discrimination on the grounds of health is still acceptable and legal. ${ }^{30}$ Merely implementing the remaining provisions of the Disability Discrimination Act (DDA) and increasing welfare benefits and services will not introduce effective civil rights for disabled people. The DDA as it stands is flawed in its acceptance of 'justifiable discrimination', its exemptions and its omission of crucial areas such as education and transport. Wholesale amendment or repealing of the DDA is necessary in order that it be replaced with legislation similar to that suggested in the Berry and Barnes Private Members' Bills. Only then can the Disability Rights Commission work fully to protect, enforce and promote the rights of disabled people. ${ }^{31}$

What is required are more comprehensive, legally enforceable anti-discrimination policies and adequate income guarantees, which are relevant to all sick and disabled people including disabled children and their families. 


\section{George Davey Smith et al.}

\section{Conclusions}

The report of the Independent Inquiry into Inequalities in Health points out, albeit in one sentence:

We consider that without a shift of resources to the less well off, both in and out of work, little will be accomplished in terms of a reduction of health inequalities by interventions addressing particular 'downstream' influences. ${ }^{2}$

Inequalities in health can only be effectively tackled by policies that reduce poverty and income inequality. Adequate living standards and protection against income insecurity are basic human rights enshrined in the Universal Declaration of Human Rights (Article 25) and the International Covenant on Economic, Social and Cultural Rights (Articles 7 and 9). Everybody should be entitled to a sufficient income to allow them to participate in the economic, social, cultural and political life of the country; this provision would also ensure the minimisation of health inequalities.

\section{Acknowledgements}

This paper is adapted from a report from the Townsend Centre for International Prosery Research at the University of Bristol which was released in response to the report of the Independent Inquiry into Inequalities in Health the Acheson Report.

\section{Notes}

(a) Standardized mortality ratios: the ratio of the number of deaths observed in the study population to the number that would be expected if the study population had the same age and sex-specific rates as the standard population, multiplied by 100 .

(b) Infant mortality rates cannot meaningfully be considered by social class before 1993 due to the exclusion of births/deaths outside marriage.

(c) Social class I includes professional occupations (e.g. accountant, electronic engineers); social class II includes managerial and technical/intermediate occupations (e.g. proprietor and managers - sales, production, works and maintenance managers); social class III non-manual includes skilled non-manual (e.g. clerks and cashiers-not retail) occupations; social class III manual includes skilled manual (e.g. drivers of road goods vehicles, metal working production fitters) occupations; social class IV includes partly skilled (e.g. storekeepers and warehousemen, machine tool operators) occupations; social class V includes unskilled (e.g. building and civil engineering labourers, cleaners etc.) occupations.

\section{References}

1. Department of Health. Public Health strategy launched to tackle the root causes of ill health. Press release 1997 (7 July).

2. Stationery Office. Independent Inquiry into Inequalities in Health. London: Stationery Office; 1998. 
3. Davey Smith G., Morris J., Shaw M. The Independent Inquiry into Inequalities in Health: a worthy successor to the Black Report? BMF 1998; 317: 1465-1466.

4. Department of Health and Social Security. Inequalities in health: report of a research working group (The Black Report). London: DHSS; 1980.

5. House of Lords. Hansard 1997 (12 February), cols 248-249.

6. Department of Social Security. Households below average income 1979-1996/7. London: Stationery Office, 1998.

7. Lynch J.W., Kaplan G.A. Understanding how inequality in the distribution of income affects health. F Health Psychol 1997; 2: 297-314.

8. Howarth C., Kenway P., Palmer G., Street C. Key indicators of poverty and social exclusion. York: Joseph Rowntree Foundation; 1998.

9. Dorling D. Death in Britain: how local mortality rates have changed: 1950s-1990s. York: Joseph Rowntree Foundation; 1997.

10. Stationery Office. On the State of the Public Health 1997: the annual report of the Chief Medical Officer of the Department of Health for the year 1997. London: Stationery Office.

11. Hattersley L. Expectation of life by social class. In: Drever F., Whitehead M., editors. Health Inequalities. London: The Stationery Office; 1997.

12. Drever F., Bunting J., Patterns \& trends in male mortality. In: Drever F., Whitehead M. (eds) Health inequalities, London: The Stationery Office.

13. Blane D., Drever F. Inequality among men in standardised years of potential life lost, 1970-73. BMF 1998; 317: 255. Years of potential life lost are the average number of years that people who have died have lost-the years of working life that they would have had if they had lived.

14. Bradshaw J., Chen J.R. Poverty in the UK: a comparison with nineteen other countries. Benefits 1997. 18: 13-17.

15. Hills J. Income and wealth: the latest evidence. York: Joseph Rowntree Foundation; 1998.

16. Goodman A., Webb S. The distribution of UK household expenditure, 1979-1992. Fiscal Studies 16: 55-78.

17. Department of Social Security. Households below average income. London: The Stationery Office, 1998.

18. Gordon D. Pantazis C. (eds) Breadline Britain in 1990's, Aldershott: Ashgate 1997.

19. Sunday Times 19th April 1996.

20. Eurostat. Unpublished analysis from the 1994 European Community Household Panel Survey Luxembourg: 1994.

21. Stationery Office. Our healthier nation. London: Stationery Office; 1997.

22. Brittan S., Webb S. Beyond the welfare state: an examination of basic incomes in a market economy. Aberdeen: David Hume Institute, Aberdeen University Press; 1990.

23. Adelman L., Bradshaw J. Children in poverty in Britain: an analysis of the Family Resources Survey 1994/95. Paper prepared as part of the ESRC project 'Poverty: the outcomes for children in the Children 5-16 Programme'. SPRU, University of York; 1998.

24. Arber S., Ginn J. Gender and inequalities in health in later life. Soc Sci Med 1993; 36: 33-46.

25. Castle B., Townsend P. We can afford the welfare state. London: T\&G; 1996.

Castle B., Davies B., Land H., Townsend P., Lynes T., Macintyre K. Fair shares for pensioners: evidence to the Pensions Review Body. Security in Retirement for Everyone, London, 1998.

26. Baldwin S., Bradshaw J., Cooke K., Glendinning C. The disabled person and cash benefits. In: Guthrie D., editor. Disability: legislation and practice. London: Macmillan; 1981.

27. Glendinning C. Losing ground: social policy and disabled people in Great Britain 1980-1990. Disability, Handicap E Society 1991; 6(1): 3-19.

28. Berthoud R., Lakey J., McKay S. The economic problems of disabled people. London: Policy Studies Institute; 1993.

29. Beresford B. Expert opinions: a national survey of parents caring for a severely disabled child. Bristol: Policy Press; 1995. 
170 George Davey Smith et al.

30. Gordon D., Heslop P. Poverty and disabled children. In: Dorling D., Simpson S., editors. Statistics in society: the arithmetic of politics. London: Arnold; 1998.

31. Heslop P. Response to the Government Green Paper on Welfare Reform. Memorandum of Evidence to the Social Services Select Committee of the House of Commons, 1998. 